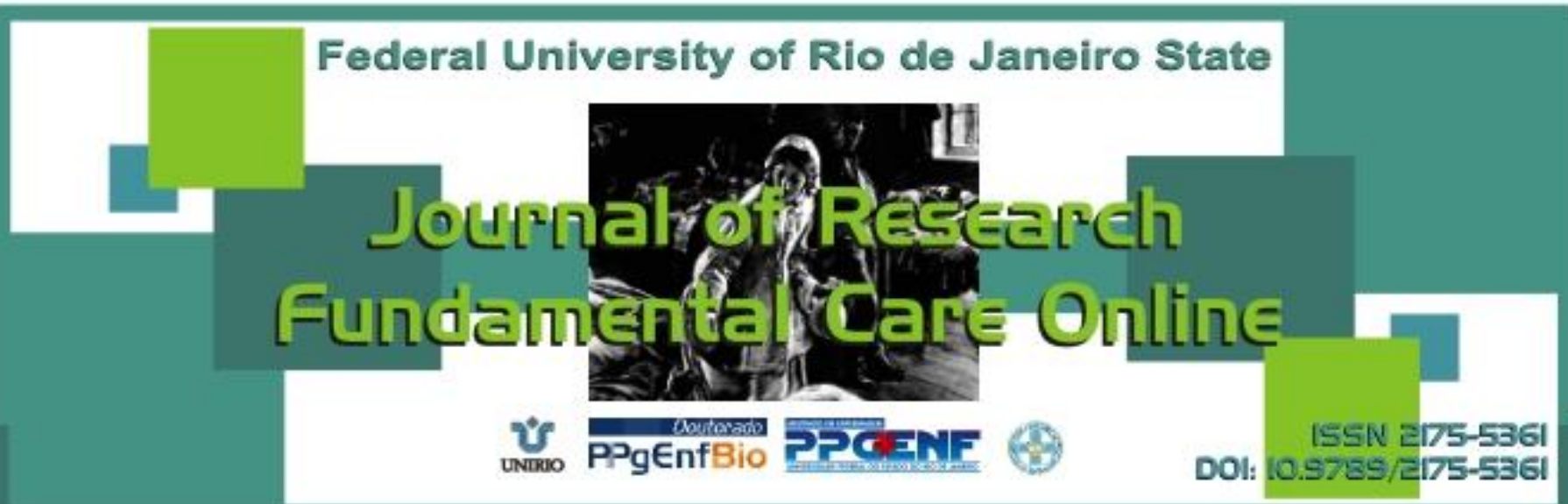

\title{
REFLECTION
}

\section{Therapeutic communication in the context of male healthcare}

Comunicação terapêutica no contexto da atenção à saúde do homem

Comunicación terapéutica en el contexto de la salud del hombre

Jocelly de Araújo Ferreira ${ }^{1}$, Jaqueline Miranda Barros Silva ${ }^{2}$, Camila Carla Dantas Soares ${ }^{3}$, Jeferson Barbosa Silva ${ }^{4}$, Rejane Millions Viana Meneses ${ }^{5}$, Bertha Cruz Enders ${ }^{6}$

Objective: This study aimed to analyze the contextual aspects of the therapeutic communication Objective: This study aimed to analyze the contextual aspects of the therapeutic communication
phenomenon between nurses and male users in the context of healthcare. Method: This is an analytical reflection, developed from a contextual analysis to understand the phenomenon. Results: The discussion of the study's phenomenon was therefore basedon the analysis of four contexts: immediate, specific, general and meta-context, allowing one conceptualization of therapeutic communication, the factors and beliefs that permeate this communication, and finally, the social prospect of the nurse and male client. Conclusion: It was concluded in this research that there is a need for therapeutic communication between the nurse and the male client so that the integral care can occur. Nurses with technical training and holistic vision will be able execute adequate therapeutic communication, expanding the vision of the male client as responsible and co-author of his own health. Descriptors: Nursing, Communication, Males.

\section{RESUMO}

Objetivo: Analisar os aspectos contextuais do fenômeno da comunicação terapêutica entre os enfermeiros e os usuários do sexo masculino homens no âmbito do cuidar. Método: Trata-se de uma reflexão analítica, desenvolvida a partir de uma análise contextual para compreensão do fenômeno estudado. Resultados: A discussão do fenômeno do estudo pautou-se, portanto, na análise de quatro contextos: imediato, específico, geral e metacontexto, possibilitando assim uma conceituação da comunicação terapêutica, os fatores e crenças que permeiam esta comunicação e, por fim, as perspectivas sociais do enfermeiro e do homem entre o enfermeiro e o homem. Conclusão: Percebeu-se com essa pesquisa que existe a necessidade da comunicação terapêutica entre o enfermeiro e o usuário do sexo masculino para que a assistência integral possa ocorrer de maneira holística. O enfermeiro com formação técnica e visão holística poderá executar adequadamente a comunicação terapêutica, ampliando a visão do homem como responsável e coautor da sua saúde. Descritores: Enfermagem, Comunicação, Gênero masculino.

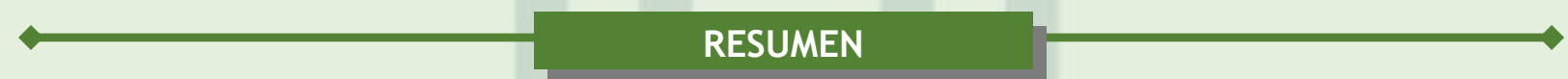

Objetivo: El estudio tuvo como objetivo analizar los aspectos contextuales del fenómeno de la comunicación terapéutica entre las enfermeras y los usuarios masculinos en el contexto de la atención. MÉTODO: Se trata una reflexión analítica, desarrollada a partir de un análisis contextual para entender el fenómeno estudiado. Resultados: La discusión sobre el fenómeno del estudio se basó en el análisis de cuatro contextos: inmediata, específica, general, y metacontexto, permitiendo así una conceptualización de lacomunicación terapéutica,factoresy creenciasque permean esta comunicacióny, por fin, las perspectivas sociales del enfermero y el hombre. Conclusión: Se observó con la investigación que hay una necesidad de comunicación terapéutica entre el enfermero y el usuario masculino para que la asistencia integral puedeocurrir de manera holístico. Los enfermeros con formación técnica y visión holísticopuede ejecutar adecuadamente la comunicación terapéutica, la ampliación de la visióndel hombre como responsable y co-autor de su salud. Descriptores: Enfermería, Comunicación, Géneros masculinos.

${ }^{1}$ Nurse, Master in Nursing, Professor oftheUndergraduateNursingCoursefrom Universidade Federal de Campina Grande/UFCG. Campina Grande (PB), Brazil. E-mail: jocellyaferreira@hotmail.com. ${ }^{2}$ Nurse. Master. Professor oftheCentro Universitário Luterano de Palmas (CEULP/ULBRA). E-mail:jaquelinemiranda26@hotmail.com. ${ }^{3}$ Nurse. Universidade Federal de Campina Grande/UFCG. Cuité (PB), Brazil. E-mail:camilacarla.soares@hotmail.com. ${ }^{4}$ Nurse, Universidade Federal de Campina Grande/UFCG. Cuité (PB), Brazil. E-mail:Jefersonbarbosa@hotmail.com. ${ }^{5}$ Nurse, PHD, Professor of the Undergraduateand Graduate Nursing Courses from Universidade Federal do Rio Grande do Norte/PPGENF/UFRN. Natal (RN), Brazil. E-mail: rejmillions@hotmail.com. ${ }^{6}$ Nurse, PHD, Professor of the Department of Nursingand of the Post graduation Program in Nursingofthe Federal Universityof Rio Grande do Norte / PPGENF / UEPB. E-mail: bertha@ufrnet.br. 


\section{INTRODUCTION}

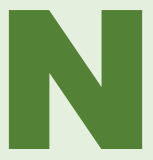

ursing is perceived as a care science and encompasses the following concepts in its essence: awareness, humanization, technical and predefined concepts, among other aspects of fundamental importance. Aiming at this caring in nursing actions, an interactive process is necessary in which the intentionality of the act, knowledge and what is expected from each one in the care process are manifested.

It reiterates that this objective, to elucidate that the legitimacy of this relationship will be guided in the meeting, with the explicit message, concise, in that all the signals emitted are perceived and decoded, leading to an effective communication. ${ }^{1}$

Based on these considerations, it is understood that the role of the nurse is not restricted to execute techniques or procedures, and yes aims to propose actions for comprehensive care involving, among other things, to develop communication skills. Therefore, communication as a basic nursing instrument is the medium used to meet the patient's needs. ${ }^{2}$

Being aware of the importance of communication in nursing work it is believed that this is to be effective, contributing significantly to prepare, plan and putting the care into practice. $^{3}$

To define the therapeutic communication, its primary aim is guided at the identification and in the patient's care during their poor health, being the form of understanding and sharing messages sent and received, exerting influence on the behavior of people involved. In the case of therapeutic communication some elements must be present: sender, receiver, message, channel and answer. ${ }^{4}$

When integrated into the relations between the persons, these elements are part of human existence, which leads to assume that every human being is in continuous communication. The nurse, in turn, is no exception to this reality, due to his contact at all levels of health care and all users, disabled or not, those with chronic diseases or not, men, women, adolescents and children.

However, despite the progress and the positive experiences reported with healthcare for certain groups of users, the problem of the human bond to services permeates the everyday life of all health areas, especially in the context of primary care. The missing link between the need and care suggests the existence of interaction and effective communication difficulties of health professionals with this population group.

Traditionally this problem is addressed in the literature by the concept of gender, insofar as the studies have been based on male identity gained through the process of socialization. ${ }^{5}$ In this perspective, the year 1970 was considered as the March of north American studies on the topic "male gender and health". such studies translating a thought exploratory also by feminist theory and politics and conceptually assumed that traditional masculinity produced health deficits. From the 1990s, the topic in question began to be 
addressed under a differentiated perspective, which considers the aspects related to health systems and the human condition. ${ }^{6}$

In Brazil, the Ministry of Health, at the beginning of the 21st century, presented the "National Policy for Integral Attention to Human Health", aligned to the National Policy of Basic Attention, that has as objective to promote health actions that contribute significantly to the understanding of singular masculine reality in its various sociocultural and political-economic contexts, in addition to the respect to the different levels of development and organization of local health systems and management types. ${ }^{7}$

Thus, are Policy principles in focus the humanization and the quality, which imply the promotion in the recognition and respect the ethics and the rights of the male population, obeying their sociocultural peculiarities. It is believed, therefore, that the therapeutic communication exercises the role of a strong strategy for the implementation of these principles, as the context in which this relationship service and male user takes place.

This study aimed to analyze the context of therapeutic communication between the nurse and the user of the male gender in health services and the elements that determine.

The theoretical contributions of contextual analysis was used as a reference for the understanding of a phenomenon. ${ }^{8}$ Among the approaches of existing context analysis in the literature, it selected this modality of understanding due to its organization in the subtopics, allowing the study and the interaction of the researcher with the object and its reality.

Therefore, it is expected that this reflection will serve as a subsidy for a better understanding of the therapeutic communication of nurses, in particular, with the user of the male gender, thus allowing an assistance that takes into account its context, as well as their research.

\section{METHODOLOGY}

This is a reflection about the analytical context of therapeutic communication of nurses in male health. Using the theoretical framework in focus, the significance of the context aspects was considered and discussed by means of the relevant literature.

In this perspective, the explanation of the context occurs at four levels: immediate, specific, general and meta-context, whose analysis phases of the phenomenon are gradual and inter-related. Therefore, aiming at better understanding of the phenomenon under investigation and a possible transformation, the event survey of reality begins with the characteristics micro that involve the process in which it happens, until reaching a macro vision on the political, theoretical and philosophical aspects. ${ }^{8}$

Thus, the analysis was performed according to contextual levels. In reflection of the immediate context we sought an approximation and conceptualization of the 
communication phenomenon; in the analysis of specific contexts and general, discussed the meanings and difficulties that permeate the effectiveness of this communication; and in meta-context, social perspectives of communication between the nurses and the male users. The results of this process were organized in topics, which together reflect the understanding gained from the phenomenon.

\section{RESULTS AND DISCUSSION}

\section{The nursing communication}

It is called communication as a therapy when it is intended to identify and meet the health needs of the patient, helping to improve the nursing practice in, creating opportunities for learning and awakening in patients feelings of confidence, allowing them to feel satisfied and secure. ${ }^{9}$

Corroborating with this, it highlights the importance of expanding the qualification of professionals in health care, both in a specialized technical dimension as in ethicalpolitical dimension, communicational and inter-personal relations, for which there is a holistic assistance. ${ }^{10}$

During the process of therapeutic communication, nurses participate simultaneously in two dimensions: the verbal, conferring a psycholinguistic repertoire and the non-verbal, conferring a psychobiological statute. ${ }^{11}$

The need for such communication between the nurse and the male user is present in all levels of care, whether in primary care, secondary or tertiary. However, addressing the answer for the male, we observed various attitudes and behaviors that may manifest as health needs, emphasizing that, in the context of primary care health units can be addressed more efficiently. For this reason, it is important that communication take a dimension where they consider these situations as something contextualized in sociocultural relations in which male users live. ${ }^{5}$

Through the practical experience and the studies conducted, the inquiry about the current situation of therapeutic communication is needed. From this, it was questioned: how communication is currently taking place for nurses with male users? As a response, it was stated that, for some nurses, the therapeutic communication represents a conversation which is related only with the clinical status of the patient; in addition, they also indicate that the patients have difficulties in identifying the nurse and to establish a bond between them that favors the therapeutic communication, due to the distance of these professionals during the visits. ${ }^{2}$ However, it is also emphasize that some nurses, consciously or not, make use of therapeutic communication and interpersonal relationship techniques.

The word "communication" has its origin in Latin comunicare, which, which means placing in common, being imperative to have an understanding of the parties involved. So 
that this understanding occurs, i.e. the communication is installed, some elements are necessary: a transmission channel, a message, a sender and a receiver. ${ }^{1}$

The authors also emphasize that the basic process of communication can occur in a verbal, non-verbal and symbolic manner. The verbal form is characterized by communication mode more known, more familiar and frequently used, it is subdivided in oral-verbal, when informs orally, and verbal-written, when occurs by means of reports, standards and/or procedures.

The non-verbal communication emerges as one of the most interesting facets of communication, to relate with all the ways that do not involve the words expressed. ${ }^{12}$ While that the symbolic form refers to the use of symbols, essential elements in the process of communication, and it is broadcast by everyday life and by the most varied aspects of human knowledge. Although there are symbols that are internationally recognized, others are only understood within a given group or context.

Analyzing the nurse's performance in the health/disease process, relations care/caregiver before the general public, and frequently studied, such as women, adolescents, children, the elderly and the users with chronic diseases such as hypertension and diabetes mellitus, among others, it was realized that there are still gaps in communication to be fulfilled. Referring to a group so little studied as the male user, it is evident that these gaps are even larger.

To raise data in the literature, it was realized that part of this shortage can be linked to how the nursing professional communicates with this user. Reflecting on the communication, which encompass the nursing care, it becomes essential to analyze how this consolidates itself and what the necessary elements to be effective, leading to a real nursepatient interaction.

Questions about the quality of effective communication of nursing professionals with the man are fundamental to the development of perception and sensitivity of nurses, the approximation of another and the possibility of full expression of what is communicated, trans-mutating into a differentiated care. Thus, it is essential that the nurse has knowledge of the concept, as well as the applicability of communicating therapeutically.

\section{Factors that influence the act of communicating}

The gender concept goes beyond a learned identity, it constitutes and is established by multiple instances and social relations, institutions, symbols, forms of social organization, speeches and doctrines; i.e., they are attributes and functions socially constructed, which configures differences and inter-relations between the genders that go beyond the biological aspects. ${ }^{6,13}$

Faced With this understanding, it becomes clear that gender relations are a factor influencer in our way of thinking and acting as human beings, which encompass the natural look and individually to achieve the entire social context.

It was evidenced that how the man builds and experiences his masculinity is related to particular ways of becoming ill and dying. However, the modes of building and experiencing masculinity are multiple and variables, as well as their mediation with the health/disease process. ${ }^{14}$ It is in this building that the gender issues gain strength.

The concept of male gender, for both the nurse and the patient, arises from childhood, associated with the first experiences with the people who perform the tasks of 
caring. After birth, the first thing to be identified is gender, bringing to the child, from that moment, to receive messages about what the society expects from them. ${ }^{15}$ In this respect, the authors emphasize that, in the case of the man, this can be seen as a provider of his family, vector and symbol of power, being a dominator and strong.

By ratifying this idea, it is stated that the masculine subjectivity is based on strength, in the field and even in machismo, which is not built alone, because the male is born and grows in a cultural environment that pushes him towards this role. Thus, the male role constructed, interpreted, internalized and personalized, depends on the specific characteristics of each society, the cycle of life and of their subjective experiences. ${ }^{16}$

By assessing the authors' observations, it is understood the importance of the influence of gender roles, in understanding of the nurse in relation to man, as well as for them self, since this perception has a significant impact in the communication carried out.

Another factor to consider with regard to the degree of education, enlightenment and knowledge of the male user. Research points out that the more education for that user would be determining for the greater ability to critically reflect on their masculinity and about its influence in their lives, interfering significantly in their access to healthcare.

Whereas with a lower level of education, the man finds himself in a position opposite to the woman and needs care presenting himself as exclusively female. This same thought remains in male individuals that possess a degree of higher education, because, although they have hegemonic ideas, having different styles of masculinity, assigning ethical and moral values, and assuming a posture as in need of healthcare services. ${ }^{6}$

In the midst of these characteristics peculiar to the male gender, the nursing professional should work the concepts and act differently with this user, in order to establish a communication guided by their own vision of life, principles and knowledge.

Thus, the competence applied to the consistent communication of the need of a human and technical preparation, the importance of listening and accurate perception of the other, as well as the possibility of using this learning as an investment in self knowledge and respect for others.

Such statements stimulate the rethinking about the commitment of universities in preparing the educator, realizing the nurse in their role as communicator. ${ }^{11}$ Assertively, it took into consideration that all nurses are educators, concerning the orientations and teachings offered to their patient. In this respect, it points out that educational reform would allow the university to occupy a decisive place in the training of men facing the freedom. $^{11}$

Corroborating with this idea, it is said that health education should be seen as a pedagogical process that requires the development of a critical and reflective thinking, allowing to unveil the reality and propose transformative actions, considering the patient as a historical and social subject able to propose and opine in healthcare decisions to take care of themselves, their family and their community. ${ }^{17}$

Therefore the assertion quoted above comes from ratifying the instances cited, with regard to education and, therefore, a space should be the transformation of the way of thinking and acting between the sexes that are culturally rooted in society. ${ }^{13}$

Meanings and difficulties of communication 
The values, beliefs and experiences experienced by nurses and by users of healthcare services to form their culture and their principles, influencing significantly in their way of communicating therapeutically.

Cultural Studies corroborate for understanding the construction of identities, being that they are developing in spaces where people live, inside and outside the community, producing meanings for those who create, transform and live in them. ${ }^{15}$

Through collective constructions and the historic moment experienced by men, the meanings are molded and the evolution of humanity and science is replaced by reflections of concepts as much as their reformulations. ${ }^{13}$

From these constructions, it was understood that, in order to avoid communication failures, it is imperative to use the senses, sensitivity, intuition and experiences in order to recognize and interpret the signs used by the patient. ${ }^{1}$

It Becomes vital for the nurse to consider the individuality, values and beliefs of patients, in addition to the relationship based on empathy and a clear language. ${ }^{1}$

However, many times the nurse has a mechanistic view, comprising the individual from a biological approach, without attention to the psychological dimensions, historical and cultural, and wanting to impose their reality on the patient. ${ }^{18}$

Communication at all levels becomes important for the growth of people as human beings, is part of the previous experience and also those acquired during each day. ${ }^{11}$

Communication, as previously stated, is present in the daily life of people. Therefore, it lacks some features, among them is therapy, widely used by nurses and other health professionals during consultations and treatments to patients. For communication to take place in an effective manner, it is necessary to use techniques used for matching and concreteness of this communication, however, when these techniques are not used correctly, ie when there are barriers in the communication process, the purpose of that communication was not achieved.

The communicational barriers, have factors that may prevent, limit or delay the development of the process of communication between people. Such factors can be cited as a limitation of the sender or the receiver, lack of capacity of concentration of attention, hypothesis of not understanding the message, imposition of schema of values, absence of common parlance and influence of unconscious mechanisms. ${ }^{4}$

Even in the face of barriers and difficulties that the communication presents, as vital function of the human being perceives that the magnitude of this communicational process is immense. In analogy, it is understood that through the communication people express what they are, are related to and satisfy their needs to promote an interaction that influences the behavior among them, reacting based on their beliefs, values, life history and culture. $^{2}$

Social perspectives of communication

Male health is not considered a subject so recent in social discussions. In the 20th century, in the 1990s, when debating on the principle of justice, which relates to the nature, becoming the professional drivers an understanding of the ethics of care with comprehensive health. ${ }^{19}$

At the beginning of the 20th century, it was found that male healthcare was little regarded by public health policies. It was also observed that, with regard to the rule on 
equal opportunity in relation to healthcare concerning the gender means the exclusion of policies that favor the male users of healthcare services, by ignoring an Institute of Men's Health. $^{16}$

Contemporaneously, there are discussions about masculinity in the area of health in general, but it is lack of studies about the masculine performance toward the healthy lifestyle and health promotion ${ }^{6 .}$

To contemplate the males in their entirety, the Health Ministry launched in November 2008 the National Policy of Integral Attention to Human Health - Principles and Guidelines -, a project that is still in phase of completion.

The Ministry of Health policy has as its main objective to promote health actions that contribute significantly to the understanding of reality singular masculine in its various sociocultural contexts and political-economic, and respect for the different levels of development and organization of local systems of health and management types. These guidelines allow for the increase in life expectancy and the reduction of rates of morbidity and mortality from preventable and avoidable causes in this population.

The The National Policy on Integrated Healthcare Human aligns with the National Primary Care, with humanization strategies in accordance with the principles of the SUS, strengthening actions in networks and services and healthcare. ${ }^{20}$

The Ministry of Health highlights that the definitive implementation of this project will be the training of health professionals, thus receiving the influence of different socioeconomic-political circumstances, as well as job market trends for the various professions that comprise the industry.

The Ministry of Education and the Ministry of Health, in order to meet the specific needs of the Brazilian population with regard to the training of human resources, the production of knowledge and the provision of services comprising the Unified Health System, have launched programs such as the National Program of Reorientation of Vocational Training in Health (PRÓ-SAÚDE), which directs the institutions of higher education. This policy offers courses in the area of health, promoting rapprochement between the formation of graduation in the country and the needs of basic healthcare, translated in Brazil by the Family Health Strategy. ${ }^{21}$

Additionally, graduate programs are structured in concentration areas, lines and research projects, groups / research groups registered in the Directory of the National Council for Scientific and Technological Development (CNPq). This allows the formation of masters and doctors with investigative powers in practical experience in the nursing profession. ${ }^{21}$

In the Brazilian reality are some postgraduate directed to human health and therapeutic communication. One such institution is the Ana Nery School of Nursing at the University of Rio de Janeiro, which worked across disciplines and research groups with the male cancer patient. ${ }^{21}$

It is perceived, with all the reflection held about the prospects of social communication, that the studies and the routing for its effectiveness, as reality therapy in the care of a male patient, is occurring significantly. However, it is still noticeable the need of investments on the part of the government, the interest of the professional to improve thier knowledge, as well as the vehemence of universities to develop research on this topic. 


\section{CONCLUSION}

Upon this context analysis, it was realized that the phenomenon of communication can be considered as an instrument of therapeutic attitude by nurses, being of fundamental importance that if get essential knowledge about the theoretical foundations of the phenomenon and which are acquired skills for this communication.

Communication, when directed to the patient, occurring in a responsible way, supportive, humanized and ethics, this way becomes therapeutic. There is to promote awareness by universities urgent role of nurses as communicators born and perception of effective assistance indispensable and vital to the users of healthcare services.

Man should be considered as a unique, equipped with feelings, experiences, sociocultural values defined throughout his existence. Thus, so that quality assistance occurs between nurse and man, regardless of the level of healthcare that this user is looking for, it is essential to use dialogic practice, by means of reflective and participatory communication, promoting healing actions, health education and behavior change. 8

All professionals and nursing students, represented by the Ministry of Health and Education, they should feel they are an integral and determinant of the development of the National Comprehensive Male Healthcare, producing full assistance to the male.

Thus, the nurse, when prepared technically and scientifically, promotes a holistic assistance, in that they know how to listen, offering an opening for the realization of questionings, using honesty and impartiality, demonstrating respect, provide sufficient time for consultation, showing genuine interest and truly speaking with the man, making this male user serviced, responsible and co-author of his health. 


\section{REFERENCES}

1. Oliveira ME, Fenili RM, Zampieri MF, Martins CR. Um ensaio sobre a comunicação no cuidado de enfermagem utilizando os sentidos. Enfermería Global, mai 2006, v 8, p 1-7; Murcia.

2. Pontes AC, Leitão IMTA, Ramos IC. Comunicação terapêutica em enfermagem: instrumento essencial do cuidado. Revista Brasileira de Enfermagem [periódico online], mai/jun, 2008 [acesso em 11 de junho de 2010], v 61, n 3, p 312-18;Brasília. Disponível em: http: / / www.scielo.br/scielo.php?script=sci_arttext\&pid=S0034-71672008000300006

3. Araújo IMA, Silva RM, Bonfim IM, Fernandes AFC. Nursing communication in nursing care to mastectomized women: a grounded theory study. Revista Latino-Americana deEnfermagem[periódico online]. 2010Feb[acesso em 12 de julho de 2010],18(1): 54-60. Disponivel em: http://www.scielo.br/scielo.php?script=sci_arttext\&pid=S0104$11692010000100009 \& \operatorname{lng}=$ en.

4. Stefanelli MC, Carvalho EC. (Orgs). A comunicação nos diferentes contextos da enfermagem. $3^{\circ}$ Ed. São Paulo, SP: Pearson Education, 2010.

5. Figueiredo W. Assistência à saúde dos homens: um desafio para os serviços de atenção primária.Ciência \& Saúde Coletiva [periódico online], jan/mar, 2005 [acesso em 12 de junho de 2010], v 10, n1, p 105-09; Rio de Janeiro. Disponível em: http: / / www.scielo.br/scielo.php?script=sci_arttext\&pid=S141381232005000100017\&lng=en\&nrm $=$ iso\&tlng $=p t$

6. Gomes R, Nascimento EF, Araújo FC. Por que os homens buscam menos os serviços de saúde do que as mulheres? As explicações de homens com baixa escolaridade e homens com ensino superior. Caderno de Saúde Pública, mar 2007, v 23, n 3, p 565-74; Rio de Janeiro.

7. Brasil. Ministério da Saúde. Secretária de Atenção à Saúde. Departamento de Ações Programáticas Estratégicas. Política Nacional de Atenção Integral à Saúde do Homem - princípios e diretrizes. Brasília: MS, 2008 [Acesso em: 19 junho 2010]. Disponível em: http://dtr2001.saude.gov.br/sas/PORTARIAS/Port2008/PT-09-CONS.pdf

8. Hinds PS, Chaves DE, Cypress SM. Context as a source of meaning and understanding. Qualitative health research, feb 1992, v 2, n1, p 61-74.

9. Oliveira PS, Nóbrega MML, Silva ATMC, Ferreira Filha MO. Comunicação terapêutica em enfermagem revelada nos depoimentos de pacientes internados em centro de terapia intensiva. RevistaEletrônica de Enfermagem [periódico online], 2005 [Acesso em: 10 junho 2010], v 7, n 1, p 54-63; Goiânia. Disponível em: http://www.revistas.ufg.br/index.php/fen/article/view/861/1035

10. Siqueira MM. As competências em saúde mental das equipes dos serviços de saúde: o caso NEAD-UFES. SMAD, Revista Eletrônica Saúde Mental Álcool e Drogas (Ed. port.)[periódico online], ago2009 [Acesso em12de julho.2010],v 5,n 2; Ribeirão Preto. Disponível em: http: / / www.revistasusp.sibi.usp.br/scielo.php?script=sci_arttext\&pid=\$180669762009000200009 \&lng=pt\&nrm=iso 
11. Braga E M, Silva M J P. Comunicação competente: visão de enfermeiros especialistas em comunicação. Acta Paulista de Enfermagem [periódico online], out/dez, 2007 [aceso em 15 de fevereiro de 2012], $v$ 20, $\mathrm{n}$ 4, $\mathrm{p}$ 410-14; São Paulo. Disponível em: http://www.scielo.br/pdf/ape/v20n4/03.pdf

12. Silva MJP. Comunicação tem remédio - a comunicação nas relações interpessoais em saúde. São Paulo: Gente, 1996.

13. Sebold LF, Waterkemper R, Martines JG, Meirelles BHS. Saúde e gênero: questões e conceitos na produção científica de enfermagem. Revista de enfermagem UERJ [periódico online], jul/set, 2008 [acesso em 12 de junho de 2010], v 16, n 3, p 415-20; Rio de Janeiro. Disponível em: http://www.facenf.uerj.br/v16n3/v16n3a20.pdf

14. Os autores respondem. Ciência \& Saúde Coletiva [periódico online], mar 2005 [Acesso em: 10 junho 2010], $\vee$ 10, $\mathrm{n}$ 1, $\mathrm{p}$ 32-4; Rio de Janeiro. Disponível em: http: / /www.scielo.br/scielo.php?script=sci_arttext\&pid=S1413-81232005000100009.

15. Baggio MA, Carvalho JN, Backes MTS, Backes DS, Meirelles BHS, Erdmann AL. O significado atribuído ao papel masculino e feminino por adolescentes de periferia. Escola Anna Nery Revista de Enfermagem [periódico online], out-dez2009 [acesso em: 10 junho 2010]; 13 (4): 872-78. Disponível em:http://www.scielo.br/pdf/ean/v13n4/v13n4a25.pdf.

16. Braz M. A construção da subjetividade masculina e seu impacto sobre a saúde do gênero masculino: reflexão bioética sobre justiça distributiva. Ciência \& Saúde Coletiva [periódico online],jan/mar 2005 [acesso em: 12 fevereiro de 2012], v 10, n1, p 97-104; Rio de Janeiro. Disponível em: http://www.scielo.br/pdf/csc/v10n1/a10v10n1.pdf

17. Machado MFAS, Monteiro EMLM, Queiroz DT, Vieira NFC, Barroso MGT. Integralidade, formação de saúde, educação em saúde e as propostas do SUS- uma revisão conceitual. Ciência e Saúde Coletiva [periódico online], mar/abr 2007 [acesso em 10 de fevereiro de 2012], v 12, n 2, $\mathrm{p}$ 335-42; Rio de Janeiro. Disponível em: http: / / www.scielo.br/scielo.php?script=sci_arttext\&pid=S1413-81232007000200009

18. Machado MMT, Leitão GCM, Holanda FUX. O conceito de ação comunicativa: uma contribuição para a consulta de enfermagem. Revista Latino-Americana de Enfermagem [periódico online], set/out 2005 [acesso em 14 de junho de 2010], v 13, n 5, p 13-15; Ribeirão Preto. Disponível em: http://www.scielo.br/scielo.php?script=sci_arttext\&pid=S010411692005000500017

19. Boff L. Ética mundial e processo da mundialização. In: HUNC, L. M.Ética. Rio de Janeiro: Uapê, 1997. p. 69-98.

20. Brasil. Ministério da Saúde. Política Nacional de Atenção Integral à Saúde do Gênero masculino - Plano de Ação Nacional (2009-2011). Brasília: MS, 2009 [Acesso em: 19 junho 2010]. Disponível em: http://portal.saude.gov.br/portal/arquivos/pdf/plano_saude_homem.pdf.

21. Erdmann AL. Formação de especialistas, mestres e doutores em enfermagem: avanços e perspectivas. Acta Paulista de Enfermagem [periódico online],2009 [acesso em 14 de fevereiro de 2012], v 22, n Especial-Nefrologia, p 551-553;São Paulo. Disponível em: http://www.scielo.br/pdf/ape/v22nspe1/21.pdf

Received on: 15/02/2013 Required for review: 12/09/2103 Approved on: 17/11/2013 Published on: 01/01/2014
Contact of the corresponding author: Jocelly de Araújo Ferreira R. Edvaldo Bezerra Cavalcante Pinho, 320, APT 102, Cabo Branco, João Pessoa-PB-Brasil-CEP:58.045-270 Email: jocellyaferreira@hotmail.com 